\title{
UN MODELO SVAR PARA LA ECONOMÍA BOLIVIANA
}

\section{Martín Palmero Pantoja}

\section{RESUMEN}

Bolivia es una economía pequeña, abierta, parcialmente dolarizada y con un esquema de tipo de cambio muy cercano a fijo. Bajo estas características la teoría económica keynesiana sustentaría que la política fiscal debería tener un efecto más importante, como instrumento de estabilización económica, en comparación con la política monetaria y que, al ser un país pequeño los choques externos debieran ser relevantes. En este trabajo se analiza cómo se propagan los shocks fiscales, monetarios y externos en la economía boliviana utilizando un modelo SVAR. Los resultados más relevantes indican que, efectivamente los shocks fiscales tienen mayor efecto sobre la actividad económica que los monetarios y, los choques externos, medidos como cambios en los precios de la energía, repercuten de manera importante sobre la inflación y en menor medida en el crecimiento.

Palabras Clave: Vectores Autorregresivos Estructurales, Política Monetaria, Política Fiscal, Choques Externos. 